Journal of Applied Pharmaceutical Science Vol. 6 (02), pp. 119-123, February, 2016

Available online at http://www.japsonline.com

DOI: $10.7324 /$ JAPS.2016.60218

ISSN 2231-3354 (cc) BY-NC-SA

\title{
Improving Dye ability and antimicrobial properties of Cotton Fabric
}

\author{
Fatma A. Mohamed, Hassan M. Ibrahim*, Elham A. El-Kharadly, Ekhlas A. El-Alfy \\ Textile Research Division, National Research Centre, Dokki, 12311, Cairo, Egypt.
}

\section{ARTICLE INFO \\ Article history: \\ Received on: $12 / 08 / 2015$ \\ Revised on: 19/11/2015 \\ Accepted on: 10/12/2015 \\ Available online: 27/02/2016}

Key words: Titanium

isopropoxide, nano zinc oxide

antimicrobial, dyeing, cotton.

\begin{abstract}
To improve the dyeability and antimicrobial activity of cotton, the cotton was treated. Firstly, Carboxymethylation was carried out in the cotton fibers to form alkali cellulose. Due to carboxymethylation, the alkali cellulose modifies the crystalline structure of cellulose and increases the accessibility of fibers to chemicals by swelling. Secondly, it padded in a solution content (5\% nano zinc oxide, $4 \%$ citric acid) or (6\% titanium isopropoxide, $4 \%$ citric acid) or in a solution of $5 \%$ nano zinc oxide, $6 \%$ titanium isopropoxide, $4 \%$ citric acid or in a solution of $7 \%$ nano zinic oxide, $7 \%$ titanium isopropoxide, $4 \%$ citric acid, at wet pick up of ca $100 \%$, then dried at $85{ }^{\circ} \mathrm{C}$ for $5 \mathrm{~min}$., and cured at $100{ }^{\circ} \mathrm{C}$ for $3 \mathrm{~min}$, the latter, we use these fabric in dyeing with synthesized acid dye and commercial basic dye finally, we measure antimicrobial activity for these fabric tow ard Gram negative and Gram positive .
\end{abstract}

\section{INTRODUCTION}

Carboxymethylated cotton was found to be a cheaper competitive for alginate fibers in the production of absorbent wound dressings (Parikh et al., 2003), Formaldehyde-based chemical finishes such as dimethylol dihydroxyethylene urea and its etherified derivative with lower formaldehyde concentrations are used to impart ease of care characteristics and durable press properties to cotton apparel. They are cost effective and efficient (Petersen, 1971, Petersen and Pai, 1981, Lewin and Sello, 1984, Bajaj, 2002). However, the free formaldehyde on the finished fabric is considered one of the major problems in easy care and durable press of cotton finishing. A variety of cellulose crosslinking agents have been investigated to provide nonformaldehyde easy care finishing, e.g. polycarboxlic acid. However, numerous disadvantages such as high cost, inadequate reactivity, fabric yellowing, excessive fabric tendering and toxicity were observed with those agents.

Such disadvantages have prevented their adoption in place of the formaldehyde- based finishes now in commercial use (Yamamoto, 1982, Welch, 1983, Welch, 1984, Welch and Peters, 1987, Trask-Morrell and Andrews, 1992). A method for nonformaldehyde easy care finishing of cotton fabric based on ionic crosslinking has been examined.

\footnotetext{
* Corresponding Author

Hassan M. Ibrahim, Textile Research Division, National Research Centre, Dokki, 12311, Cairo, Egypt. Email: hmaibrahim@gmail.com
}

Accordingly, the cotton fabric was first partially carboxymethylated to impart to it the anionic character through its reaction with monochloroacetic acid in alkaline medium. Application of reactive cationic agent in alkaline medium affects crosslinking of the resulting anionic cotton in a second step (Hashem et al., 2005). With this increase in health awareness, many people focused their attention on educating and protecting themselves against harmful pathogens. It soon became more important for antimicrobially finished textiles to protect the wearer from bacteria than it was to simply protect the garment from fiber degradation (Yadav et al., 2006). The need for antimicrobial textiles goes hand-in-hand with the rise in resistant strains of microorganisms. Functional textiles include everything from antimicrobial finished textiles, to durable, or permanent press finished garments, to textiles with self-cleaning properties, and textiles with nanotechnology. With the above back ground information the present study was carried out with the main objective of evolving a simple method for the synthesis of zinc oxide nanoparticles, design a method to finish zinc oxide nanoparticles onto cotton fabrics to confer antimicrobial function and finally evaluate the finished fabrics in terms of antibacterial, wash durability and topographical function (Rajendra et al., 2010). TiO2 have been investigated extensively for the killing or growth inhibition of bacteria (Sunada et al., 2003, Fu et al., 2005). Hence, a combination of hydroxyapatite and $\mathrm{TiO} 2$ to form a composite has the ability to absorb and decompose bacteria and organic materials and is considered to be good in antibacterial applications and environmental purifications and also for 
Photocatalytic decomposition of biomaterials, such as proteins and lipids (So et al., 1997; Nonami et al., 1998; Wu and Nancollas, 1998).

In this research carboxymethylated cotton fabric contain $335 \mathrm{meg} / 100 \mathrm{~cm}$ cellulose prepared according to a method mentioned elsewhere (Yi et al., 2007). After that, different samples of this fabric were padded in different solutions of:

A. Zn acetate dehydrate $(5 \%)$ and $(4 \%)$ citric dried at $85^{\circ} \mathrm{C}$ for $5 \mathrm{~min}$. and cured at $100^{\circ} \mathrm{C}$ for $3 \mathrm{~min}$.

B. $(3 \%)$ solution of nano $\mathrm{Zn}$ oxide of average size particle range between (19-14nm) were prepared according to a method mention elsewhere (Hashem et al., 2005)

C. $(6 \%)$ sodium hypophosphate and $(4 \%)$ citric acid dried at $85^{\circ} \mathrm{C}$ for $3 \mathrm{~min}$. and cured at $160^{\circ} \mathrm{C}$ for $3 \mathrm{~min}$.

D. (4\%) solution of titanium isopropoxide emulsion and $(3 \%)$ citric acid dried at $85^{\circ} \mathrm{C}$ for $3 \mathrm{~min}$. and cured at $110^{\circ} \mathrm{C}$ for $5 \mathrm{~min}$.

The present work is under taken with a view of studying the improving of dyeability and antimicrobial activity by treatment the cotton by Carboxymethylation and then padding in nano zinc oxide $\%$ or titanium isopropoxide $\%$ or in both of them, after that we dyeing cotton by synthesized acid and basic dye, then we measure K/S, fastness and antimicrobial of cotton.

\section{EXPERIMENTAL}

\section{Materials}

A desired and scoured loom state(100\%) cotton (333 meq./ 100 gm fabric) was prepared according to a method mention else-where (Hashem et al., 2005). The basic dye is methylene blue and we synthesized acid dye (Mohamed and Melad Mohareb, 2013) as mention below section 2.2

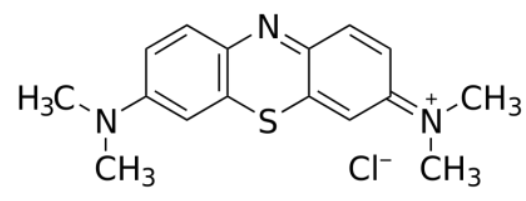

Methylene blue

\section{Synthesis of acid dyes}

The compound of ethyl 2-Amino -4, 5, 6, 7tetrahydrobenzo[b]thiophene-3-carboxylate $\mathbf{1}$ was prepared as reported method (Kim et al., 2001).by adding cyclohexanone (0.1 mole, $9.8 \mathrm{ml})$ to ethylcyanoacetate $(0.1 \mathrm{~mole}, 11.3 \mathrm{ml})$ with sulphur metal $(0.1$ mole, $3.2 \mathrm{gm})$ then dissolving all the reactants in absolute ethanol with small catalytic amount of triethylamine and refluxed for one hour. The compound precipitated by concentrated hydrochloric acid and crushed ice, filtrated and dried. The compound $\mathbf{1}$ ( $2.25 \mathrm{~g}, 0.01$ mole, was cooled to $0-5 \mathrm{C}$ and then treated with concentrated hydrochloric acid $(5 \mathrm{ml})$ then a solution of sodium nitrite $\left(0.70 \mathrm{~g}, 0.01\right.$ mole in $\left.10 \mathrm{ml} \mathrm{H}_{2} \mathrm{O}\right)$ was added to obtain the diazonium salt.

After complete diazotization, the diazonium salt solution was coupled with $\gamma$-acid (2.39 g, 0.01 mole) 2-amino-8- naphthol- 6-sulphonic at $\mathrm{pH} 2-3$ and 0-5 ${ }^{\circ} \mathrm{C}$. The resultant monoazo dye 2 was filtrated and dried under vacuum at $50^{\circ} \mathrm{C}$ (scheme 1)

2-azo [(4,5,6,7-tetrahydrobenzo [b]thiophene)3ethylcarboxylate)2-yl]7-amino-3-hydroxy-naphthalene- 5 sulphonic acid, sodium salt-. (scheme 1)

Dye 2: violet, $\lambda_{\max } 565$ m.p. $>300 \mathrm{C}$, yield $80 \%$ $\mathrm{C}_{21} \mathrm{H}_{21} \mathrm{~N}_{3} \mathrm{O}_{6} \mathrm{~S}_{2} \mathrm{Na}(498)\left[\mathrm{M}^{+}\right]=498$. Calculated: $\mathrm{C}, 50.60 ; \mathrm{H}, 4.21$; N, 8.43 ; S, 12.85\%, Found: C; 50.23; H, 4.49; N, 8.73; S, 12.57 $\%\left(\mathrm{IR}\left(\mathrm{v}, \mathrm{cm}^{-1}\right): \quad 3500-3400\left(\mathrm{OH}, \mathrm{NH}_{2}\right), 1671(\mathrm{C}=\mathrm{O}), 1500\right.$ $(\mathrm{N}=\mathrm{N}) .{ }^{1} \mathrm{HNMR}(\delta, \mathrm{ppm}): 2.05\left(\mathrm{t}, 3 \mathrm{H}\right.$, ester $\left.\mathrm{CH}_{3}\right), 2.38-2.48(\mathrm{~m}$, $8 \mathrm{H}, 4 \mathrm{CH}_{2}$ ), 3.60 (q, $2 \mathrm{H}$, ester $\left.\mathrm{CH}_{2}\right), 7.17\left(\mathrm{~s}, 2 \mathrm{H}, \mathrm{NH}_{2}\right)$ 7.41-7.85 ( $\mathrm{d}, 3 \mathrm{H}$, naphthyl) 7.97 (t, 1H, naphthyl) $13.21(\mathrm{~s}, 1 \mathrm{H}, \mathrm{OH})$.

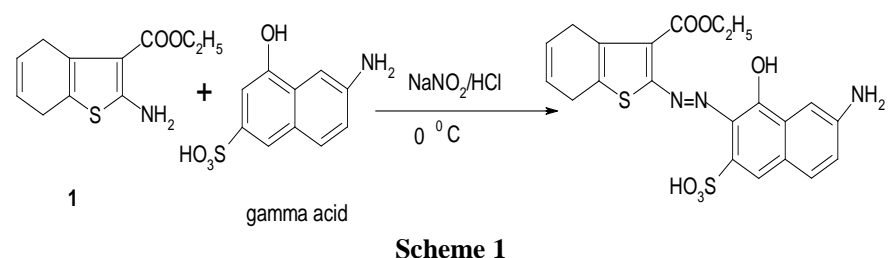

Preparation of pre-treatment fabric

The prepared fabric was divided into strips one them was padded in a solution content (7\% zinc acetate, $4 \%$ citric acid), the second in (7\% nano zinc oxide, $4 \%$ citric acid), the third strip in (7\% nano zinc oxide, $7 \%$ titanium isopropoxide, $4 \%$ citric acid). All samples after padding process at wet pick up of ca $100 \%$ dried at $85^{\circ} \mathrm{C}$ for $5 \mathrm{~min}$. and the last strip is blank.

\section{Dyeing procedures \\ Methylene blue}

In the dyeing process, the amount of dyes applied was $2 \%$ of weight of fabric (wof), liquor ratio $40: 1$. Temperature was elevated at heating rate of $2^{\circ} \mathrm{C} / \mathrm{min}$ to reach the recommended temperature of $80{ }^{\circ} \mathrm{C}$ for conventional dyeing and left for $30 \mathrm{~min}$. Then samples were air-dried.

\section{Acid dyeing (we synthesized)}

The treated cotton fabric was dyed at $80^{\circ} \mathrm{C}$ over $30 \mathrm{~min}$. with the liquor ratio of $40: 1$. Then, the cotton was dried in air.

\section{Measurements and Testing Dye Exhaustion}

Uptake of the basic and acid dye by the cotton pretreated was measured by sampling the dyebath before and after dyeing on a Shimadzu UV-2401PC UV/V is spectrophotometer at the $\lambda_{\max }$ value using a calibration curve previously obtained using known dye concentrations $(\mathrm{g} / \mathrm{L})$. The percentage of dyebath exhaustion $(\% E)$ was calculated using Eq. 1.

$$
\% E=\left[1-\left(C_{2} / C_{1}\right)\right]_{\times 100}
$$

Where $C_{1}$ and $C_{2}$ are the dye concentrations in the dyebath before and after dyeing, respectively. 


\section{Colour measurements}

The colour parameters of the un-dyed and dyed the cotton pretreated were determined using an Ultra Scan PRO spectrophotometer (Hunter Lab) with a D65 illuminant and $10^{\circ}$ standard observer (Hu et al., 1987, Savarino et al., 1989). The corresponding $K / S$ values were calculated from the reflectance data at $\lambda$ max of the dyeing

\section{Fastness Testing}

Dyed the cotton pretreated samples, after washing-off using $2 \mathrm{~g} / \mathrm{L}$ nonionic detergent at $80^{\circ} \mathrm{C}$ for $15 \mathrm{~min}$, were tested by standard ISO methods. Wash fastness (ISO 105-C02 (1989), crock fastness (ISO 105-X12 (1987), and fastness to perspiration (ISO 105-E04 (1989) were evaluated using the visual ISO Gray Scale for both color change (AATCC Evaluation Procedure (EP) 1similar to ISO 105-A02) and color staining (AATCC EP 2-same as ISO 105-A03). Light fastness (carbon arc) was evaluated using ISO 105-B02.

\section{Evaluation of antibacterial activity in vitro}

\section{Materials}

Two bacterial strains from the Faculty of women for Art, Science and Education, Ain Shams University, Cairo, Egypt were employed. They include Staphylococcus aureus (S. aureus) as Gram-positive $(\mathrm{G}+\mathrm{ve})$ bacteria: and Escherichia coli (E. coli) as the Gram-negative $(\mathrm{G}-\mathrm{ve})$ bacteria. Fresh inoculants for antibacterial assessment were prepared on nutrient broth at $37{ }^{\circ} \mathrm{C}$ for $24 \mathrm{~h}$.

\section{Disk diffusion Test method:}

The antibacterial activity of treated and dyed samples was determined against the test bacteria by disk diffusion method on an agar plate (Seyam et al., 2012, Abou-Zeid et al., 2013).

\section{RESULTS AND DISCUSSION}

The cotton fabrics were pretreated with Carboxymethylation and padding in \% nano zinc oxide or titanium isopropoxide then dyed with synthesized acid dye and commercial basic dye have antimicrobial activity and have fastness and colour strength according to their structure. So we can notice that the cotton fabric with acid dye $\mathbf{3}$ is the highest strength than others which prepared by titanium isopropoxide and zinc nano oxide and the lowest strength which blank. In the cotton fabric with basic dye we can notice that the cotton fabric with basic dye $\mathbf{4}$ is the highest strength than others which prepared by titanium isopropoxide and nano zinc oxide and the lowest strength which prepared by zinc acetate only.

\section{Colorimetric and Fastness properties}

The colorimetric CIE $\mathrm{L} * \mathrm{a} * \mathrm{~b} * \mathrm{C} * \mathrm{~h}^{\circ}$ data of the dyed cotton fabric was pretreated using acid dye and basic dye are shown in table $\mathbf{1 , 2}$ respectively and The colorimetric CIE $\mathrm{L} * \mathrm{a} * \mathrm{~b} * \mathrm{C} * \mathrm{~h}^{\mathrm{o}}$ data of the undyed cotton fabric are shown in table $\mathbf{3}$.
Table 1: Colorimetric data of the dyed cotton fabric was pretreated using acid dye $\left(2 \%\right.$ wof) at $80{ }^{\circ} \mathrm{C}$

\begin{tabular}{ccccccc}
\hline $\max \Lambda$ & sample & $\Delta \mathbf{E}$ & $\mathbf{K} / \mathbf{S}$ & $\mathbf{L}^{*}$ & $\mathbf{a}^{*}$ & $\mathbf{b}^{*}$ \\
\hline \multirow{4}{*}{$\mathbf{5 5 0}$} & $\mathbf{1}$ & 57.07 & 1.60 & 55.56 & 9.03 & -9.41 \\
& $\mathbf{2}$ & 65.32 & 0.78 & 64.85 & 6.20 & -4.79 \\
& $\mathbf{3}$ & 64.32 & 0.85 & 63.73 & 7.43 & -4.53 \\
& $\mathbf{4}$ & 56.40 & 1.69 & 54.80 & 10.28 & -8.52 \\
& $\mathbf{5}$ & 69.86 & 0.52 & 69.62 & 5.64 & -1.48 \\
\hline
\end{tabular}

Table 2: Colorimetric data of the dyed cotton fabric was pretreated using basic dye ( $2 \%$ wof) at, $80{ }^{\circ} \mathrm{C}$.

\begin{tabular}{ccccccc}
\hline $\max _{\Lambda}$ & sample & $\Delta \mathbf{E}$ & $\mathbf{K} / \mathbf{S}$ & $\mathbf{L}^{*}$ & $\mathbf{a}^{*}$ & $\mathbf{b}^{*}$ \\
\hline \multirow{6}{*}{$\mathbf{6 1 5}$} & $\mathbf{1}$ & 69.36 & 1.24 & 67.20 & -14.16 & -9.69 \\
& $\mathbf{2}$ & 61.52 & 4.20 & 54.69 & -13.85 & -24.52 \\
& $\mathbf{3}$ & 62.56 & 4.01 & 55.44 & -13.84 & -25.47 \\
& $\mathbf{4}$ & 58.19 & 6.73 & 48.73 & -11.24 & -29.75 \\
& $\mathbf{5}$ & 53.49 & 5.37 & 48.20 & -12.26 & -19.69 \\
\hline
\end{tabular}

Table 3: Colorimetric data of the undyed cotton fabric was pretreated of whiteness and yellowness.

\begin{tabular}{ccccc}
\hline sample & $\Delta \mathbf{E}$ & $\mathbf{K} / \mathbf{S}$ & $\mathbf{W}$ & $\mathbf{Y}$ \\
\hline $\mathbf{1}$ & 84.65 & 0.44 & 21.40 & 18.16 \\
$\mathbf{2}$ & 86.86 & 0.22 & 52.94 & 6.74 \\
$\mathbf{3}$ & 87.62 & 0.30 & 47.89 & 9.26 \\
$\mathbf{4}$ & 88.74 & 0.24 & 55.60 & 7 \\
$\mathbf{5}$ & 83.41 & 0.53 & 17.66 & 18.48 \\
\hline
\end{tabular}

The colour parameters were evaluated by means of the Cielab system and the modified CIE $\mathrm{L}^{*} \mathrm{C} * \mathrm{~h}^{\mathrm{o}}\left(\mathrm{D} 65 / 10^{\circ}\right)$ system. The following colour parameters for the dyed samples were obtained by the digital Cielab system: L* - lightness, $\mathrm{a}^{*}$ - redness if positive coordinate, or greenness if negative coordinate, $b^{*}-$ yellowness if positive coordinate, or blueness if negative coordinate. As shown in table 4, the fastness to washing, rubbing and perspiration of all samples dyed with the dye were excellent to very good irrespective to the fabric used.

A color space can be described as a method for expressing the color of an object using some kind of notation, such as numbers. Commission International de l'Eclairage (CIE), a nonprofit organization considered to be the authority on the science of light and color, has defined color spaces, including CIE XYZ, CIE $\mathrm{L} * \mathrm{a} * \mathrm{~b} *$, and $\mathrm{CIE} \mathrm{L} * \mathrm{C} * \mathrm{~h}$, for communicating and expressing object color. These systems allow users to evaluate color attributes, identify inconsistencies, and accurately express their findings to others in numerical terms.

The $\mathrm{L} * \mathrm{C} * \mathrm{~h}$ color space, similar to CIELAB, is preferred by some industry professionals because its system correlates well with how the human eye perceives color. It has the same diagram as the $\mathrm{L}^{*} \mathrm{a} * \mathrm{~b} *$ color space but uses cylindrical coordinates instead of rectangular coordinates.

In this color space, $\mathrm{L}^{*}$ indicates lightness, $\mathrm{C}^{*}$ represents chroma, and $\mathrm{h}$ is the hue angle. The value of chroma $\mathrm{C}^{*}$ is the distance from the lightness axis $\left(\mathrm{L}^{*}\right)$ and starts at 0 in the center. Hue angle starts at the $+\mathrm{a}^{*}$ axis and is expressed in degrees (e.g., $0^{\circ}$ is $+a^{*}$, or red, and $90^{\circ}$ is $+b$, or yellow) (Colorimetry, 1976, Hunter and Harold, 1987). 
Table 4: Fastness properties of dyed cotton fabrics using acid and basic dyes ( $2 \%$ wof) at $80^{\circ} \mathrm{C}$.

\begin{tabular}{|c|c|c|c|c|c|c|c|c|c|c|c|c|c|}
\hline \multirow{3}{*}{ sample } & \multirow{3}{*}{ dye } & \multirow{2}{*}{\multicolumn{2}{|c|}{$\begin{array}{c}\begin{array}{c}\text { Fastness to } \\
\text { rubbing }\end{array} \\
\end{array}$}} & \multirow{2}{*}{\multicolumn{3}{|c|}{ Wash fastness }} & \multicolumn{6}{|c|}{ Fastness to Perspiration } & \multirow{3}{*}{ Light } \\
\hline & & & & & & & & Ikali & & & Acidi & & \\
\hline & & Dry & Wet & Alt & SC & SW & Alt & $\mathbf{S C}$ & SW & Alt & SC & SW & \\
\hline \multirow[t]{2}{*}{1} & acid & $4-5$ & $4-5$ & $4-5$ & $4-5$ & $4-5$ & $4-5$ & $4-5$ & $4-5$ & $4-5$ & $4-5$ & $4-5$ & 4 \\
\hline & base & $4-5$ & $4-5$ & $4-5$ & $4-5$ & $4-5$ & $4-5$ & $4-5$ & $4-5$ & $4-5$ & $4-5$ & $4-5$ & 5 \\
\hline \multirow[t]{2}{*}{2} & acid & $4-5$ & $4-5$ & $4-5$ & $4-5$ & $4-5$ & $4-5$ & $4-5$ & $4-5$ & $4-5$ & $4-5$ & $4-5$ & 4 \\
\hline & base & $4-5$ & $4-5$ & $4-5$ & $4-5$ & $4-5$ & $4-5$ & $4-5$ & $4-5$ & $4-5$ & $4-5$ & $4-5$ & 5 \\
\hline \multirow[t]{2}{*}{3} & acid & $4-5$ & $4-5$ & $4-5$ & $4-5$ & $4-5$ & $4-5$ & $4-5$ & $4-5$ & $4-5$ & $4-5$ & $4-5$ & 4 \\
\hline & base & $4-5$ & $4-5$ & $4-5$ & $4-5$ & $4-5$ & $4-5$ & $4-5$ & $4-5$ & $4-5$ & $4-5$ & $4-5$ & 5 \\
\hline \multirow[t]{2}{*}{4} & acid & $4-5$ & $4-5$ & $4-5$ & $4-5$ & $4-5$ & $4-5$ & $4-5$ & $4-5$ & $4-5$ & $4-5$ & $4-5$ & 4 \\
\hline & base & $4-5$ & $4-5$ & $4-5$ & $4-5$ & $4-5$ & $4-5$ & $4-5$ & $4-5$ & $4-5$ & $4-5$ & $4-5$ & 5 \\
\hline \multirow[t]{2}{*}{5} & acid & $4-5$ & $4-5$ & $4-5$ & $4-5$ & $4-5$ & $4-5$ & $4-5$ & $4-5$ & $4-5$ & $4-5$ & $4-5$ & 4 \\
\hline & base & $4-5$ & $4-5$ & $4-5$ & $4-5$ & 4-5 & $4-5$ & $4-5$ & $4-5$ & 4-5 & 4-5 & $4-5$ & 5 \\
\hline
\end{tabular}

Alt. colour change of dyed sample; SC, staining on cotton; SW staining on wool.

The three coordinates of CIELAB represent the lightness of the color $\left(\mathrm{L}^{*}=0\right.$ yields black and $\mathrm{L}^{*}=100$ indicates diffuse white; specular white may be higher), its position between $\mathrm{red} / \mathrm{magenta}$ and green $\left(\mathrm{a}^{*}\right.$, negative values indicate green while positive values indicate magenta) and its position between yellow and blue ( $b^{*}$, negative values indicate blue and positive values indicate yellow) (Robertson, 1977). The asterisk (*) after L, a and $b$ are part of the full name, since they represent $L^{*}, a^{*}$ and $b^{*}$, to distinguish them from Hunter's L, a, and b, described below.

\section{Antibacterial Activity of treated and dyed CMC Fabrics:}

For assessment of antibacterial activity, treated samples (with $\mathrm{Zn}$ acetate dihydrate (7\%) and citric acid (4\%) "Sample 1"; nano $\mathrm{Zn}$ with average particle size between $(14-19 \mathrm{~nm})$ and citric acid (4\%) "Sample 2"; titanium isopropoxide (7\%) and citric acid (4\%) "Sample 3"; titanium isopropoxide (7\%), citric acid (4\%) and nano $\mathrm{Zn}$ with average particle size between (14-19 nm) "Sample 4" and cotton sample as blank sample treated with titanium isopropoxide (7\%) and citric acid (4\%) "Sample 5"), subjected to disk diffusion test method The effect of metal salt and metal nano particles, and dye (acid and basic) on antibacterial activity studied and the results are listed in Table 1. The zone of inhibition (diameter) was recorded in each case. The results of undyed and untreated samples show clear growth of bacteria under them with no zone of inhibition, indicating that the untreated and undyed fabric by itself does not inhibit bacterial activity. The investigated metal salt and metal nanoparticles treatment inhibit bacterial growth, which is evidence of the absence of bacterial growth with all used dyes. It was observed that the metal salt shows antibacterial activity on both Gram positive and Gram negative bacteria, metal salt has more effective inhibition on $\mathrm{S}$. aureus than E. coli (Abou-Zeid et al., 2011, Ibrahim et al., 2013). Due to their different cell walls. S. aureus, a typical Gram-positive bacterium, its cell wall is fully composed of peptide poly glycogen, which allow foreign molecules to come into the cell without difficulty. But, the cell wall of E. coli, a typical Gramnegative bacterium outer membrane constituted of lipopolysaccharide, lipoprotein and phospholipids, and has potential barrier against foreign molecules (Sun et al., 2006, Kong et al., 2008, Abou-Zeid et al., 2011).
Although metal nanoparticles has the same effect on both Gram positive and Gram negative bacteria due to nano structure of Zinc nanoparticles (El-Sheikh et al., 2013, El-Sheikh and Ibrahim, 2014, Hassabo et al., 2015). Table 1 shows also the antibacterial activity of the treated samples dyed with both acid and basic dyes. These dyed samples show antibacterial activity due to the presence of cationic ammonium salt nature in methylene blue as base dye and the presence of varies functional groups in acid dye e.g. amino group, sulfonic group, carboxylic and azo groups which can act bacterium cells in acidic medium (Farouk et al., 2013).

Table 5: Antibacterial activity of treated and dyed CMC Fabrics.

\begin{tabular}{|c|c|c|c|c|c|c|}
\hline \multirow{2}{*}{$\begin{array}{c}\text { Sample No. } \\
\begin{array}{c}\text { Antibacterial activity } \\
(\mathrm{Z} \mathrm{I}, \mathrm{mm})\end{array}\end{array}$} & \multicolumn{2}{|c|}{$\begin{array}{c}\text { Nanoparticle } \\
\text { treated }\end{array}$} & \multicolumn{2}{|c|}{$\begin{array}{c}\text { Acid Dye } \\
\text { treated }\end{array}$} & \multicolumn{2}{|c|}{$\begin{array}{c}\text { Basic Dye } \\
\text { treated }\end{array}$} \\
\hline & 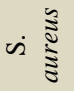 & $\begin{array}{l}: 0 \\
8 \\
i\end{array}$ & $\dot{v} \underset{\vdots}{\stackrel{\Xi}{\Xi}}$ & $\begin{array}{l}: 0 \\
0 \\
0\end{array}$ & 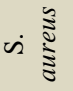 & $\begin{array}{l}: 0 \\
0 \\
\text { Ii }\end{array}$ \\
\hline 1 & 10.5 & 5.0 & 12.0 & 7.0 & 10.5 & 6.5 \\
\hline 2 & 19 & 18.0 & 21 & 20.0 & 18.5 & 15.5 \\
\hline 3 & 11.5 & 5.0 & 17.0 & 10.0 & 14.0 & 8.0 \\
\hline 4 & 19.0 & 17.0 & 24.0 & 22.5 & 16.0 & 11.5 \\
\hline 5 & 0.0 & 0.0 & 9.0 & 4.0 & 11.0 & 10.0 \\
\hline
\end{tabular}

\section{CONCLUSION}

The dyeability and antimicrobial activity of cotton fabric was improved through carboxymethylation to form alkali cellulose. Then padding the fabric in a solution content $(5 \%$ nano zinc oxide, $4 \%$ citric acid) or (6\% titanium isopropoxide, $4 \%$ citric acid) or (7\% nano zinc oxide, $7 \%$ titanium isopropoxide, $4 \%$ citric acid). After dyeing the treated fabric with acid dye or basic dye, we can notice that the treatment with (nano zinc and titanium isopropoxide) has the highest antimicrobial activity than other. Fastness to washing, rubbing and perspiration of all samples dyed were excellent to very good.

\section{REFERANCES}

Abou-Zeid N, Waly A, Kandile N, Rushdy A, El-Sheikh M, Ibrahim H. Preparation, characterization and antibacterial properties of cyanoethylchitosan/cellulose acetate polymer blended films. Carbohydrate Polymers, 2011; 84 (1): 223-230.

Abou-Zeid N, Waly A, Kandile N, Rushdy A, El-Sheikh MA, Ibrahim H. Carboxymethylchitosan/Vi Scose Blended Films: Preparation, 
Characterization And Antibacterial Properties. Journal of Materials Science and Engineering with Advanced Technology, 2013; 7 (2): 93 123.

Bajaj P. Finishing of textile materials. Journal of Applied Polymer Science, 83 (3): 631-659.

Colorimetry C. official recommendations of the International Commission on Illumination. Paris: Commission Internationale de l'Èclairage [International Commission on Illumination],

El-Sheikh M, El Gabry L,Ibrahim H. Photosynthesis of carboxymethyl starch-stabilized silver nanoparticles and utilization to impart antibacterial finishing for wool and acrylic fabrics. Journal of Polymers, 2013

El-Sheikh M,Ibrahim H. One Step Photopolymerization of N, N-Methylene Diacrylamide and Photocuring of Carboxymethyl StarchSilver Nanoparticles onto Cotton Fabrics for Durable Antibacterial Finishing. International Journal of Carbohydrate Chemistry, 2014

Farouk R, Youssef Y, Mousa A,Ibrahim H. Simultaneous Dyeing and Antibacterial Finishing of Nylon 6 Fabric Using Reactive Cationic Dyes. World Applied Sciences Journal, 2013; 26 (10): 12801287.

Fu G, Vary PS,Lin C-T. Anatase $\mathrm{TiO} 2$ nanocomposites for antimicrobial coatings. The Journal of Physical Chemistry B, 2005; 109 (18): 8889-8898

Hashem M, Refaie R,Hebeish A. Crosslinking of partially carboxymethylated cotton fabric via cationization. Journal of Cleaner Production, 2005; 13 (9): 947-954.

Hassabo AG, Nada AA, Ibrahim HM,Abou-Zeid NY. Impregnation of silver nanoparticles into polysaccharide substrates and their properties. Carbohydrate Polymers, 2015; 122 343-350.

Hu J-z, Skrabal P,Zollinger H. A comparison of the absorption spectra of a series of blue disperse dyes with the colorimetric evaluation of their dyeings. Dyes and Pigments, 1987; 8 (3): 189-209.

Hunter RS,Harold RW, The measurement of appearance1987: John Wiley \& Sons.

Ibrahim N, Eid B, Youssef M, Ibrahim H, Ameen H, Salah A. Multifunctional finishing of cellulosic/polyester blended fabrics. Carbohydrate Polymers, 2013; 97 (2): 783-793.

Kim JJ, Funabiki K, Muramatsu H, Shibata K, Kim SH, Shiozaki H, Hartmann H, Matsui M. Synthesis, structure, and UV-VIS absorption spectra of azo dyes derived from (dialkylamino) thiazole dimers. Journal of the Chemical Society, Perkin Transactions 2, (3): 379 387.

Kong M, Chen XG, Liu CS, Liu CG, Meng XH,Yu LJ. Antibacterial mechanism of chitosan microspheres in a solid dispersing system against E. coli. Colloids and Surfaces B: Biointerfaces, 2008; 65 (2): 197-202

Lewin M,Sello SB. Handbook of fiber science and technology: Volume II. Chemical processing of fibers and fabrics. Functional finishes. Part B.

Mohamed FA,Melad Mohareb R. Synthesis and applications of new bifunctional dyes bis (monochlorotriazine) based on tetrahydrobenzo [b] thiophene moiety. Pigment \& Resin Technology, 2013; 42 (4): 264 270 .

Nonami T, Taoda H, Hue NT, Watanabe E, Iseda K, Tazawa M,Fukaya M. Apatite formation on TiO 2 photocatalyst film in a pseudo body solution. Materials Research Bulletin, 1998; 33 (1): 125-131.

Parikh D, Sachinvala N, Calamari T,Negulescu I. Carboxymethylated cotton for moist wound healing. AATCC review, 2003; 3 (6): 15-19.

Petersen H. Advances in the Chemistry of N-Containing Cross-Linking Agents. Textile Research Journal, 1971; 41 (3): 239-254.
Petersen H,Pai P. Reagents for low-formaldehyde finishing of textiles. Textile Research Journal, 1981; 51 (4): 282-302.

Rajendra R, Balakumar C, Ahammed HM, Jayakumar S, Vaideki K, Rajesh E. Use of zinc oxide nano particles for production of antimicrobial textiles. International Journal of Engineering, Science and Technology, 2010; 2 (1): 202-208.

Robertson AR. The CIE 1976 Color-Difference Formulae. Color Research \& Application, 2 (1): 7-11

Savarino P, Viscardi G, Carpignano R, Barni E,Ferrero G. Disperse and cationic dyes from aminophenyl-X-Azolo-pyridines. Dyes and Pigments, 1989; 11 (3): 163-172.

Seyam A-F, Hudson SM, Ibrahim HM, Waly AI,Abou-Zeid NY. Healing performance of wound dressing from cyanoethyl chitosan electrospun fibres. Indian Journal of Fibre \& Textile Research, 2012; 37 205-210

So WW, Park SB, Kim KJ,Moon SJ. Phase transformation behavior at low temperature in hydrothermal treatment of stable and unstable titania sol. Journal of colloid and interface science, 1997; 191 (2): 398-406.

Sun L, Du Y, Fan L, Chen X,Yang J. Preparation, characterization and antimicrobial activity of quaternized carboxymethyl chitosan and application as pulp-cap. Polymer, 2006; 47 (6): 1796-1804.

Sunada K, Watanabe T,Hashimoto K. Bactericidal activity of copper-deposited $\mathrm{TiO} 2$ thin film under weak UV light illumination. Environmental science \& technology, 2003; 37 (20): 4785-4789.

Trask-Morrell B,Andrews BK. Thermoanalytical Ranking of Catalysts for Use with Polycarboxylic Acids as Durable Press Reactants1 Textile Research Journal, 1992; 62 (3): 144-150.

Welch C. Glyoxal-glycol mild cure process. Formaldehyde Free Durable Press Finish Cotton Textile Chem Color, 1984; 16 265-270.

Welch CM. Glyoxal as a Formaldehyde-Free Durable Press Reagent for Mild Curing Applications'. Textile Research Journal, 1983; 53 (3): $181-186$

Welch CM,Peters JG. Low, medium, and high temperature catalysts for formaldehyde-free durable press finishing by the glyoxalglycol process. Textile Research Journal, 1987; 57 (6): 351-356.

$\mathrm{Wu}$ W,Nancollas GH. Kinetics of heterogeneous nucleation of calcium phosphates on anatase and rutile surfaces. Journal of colloid and interface science, 1998; 199 (2): 206-211.

Yadav A, Prasad V, Kathe A, Raj S, Yadav D, Sundaramoorthy $\mathrm{C}$,Vigneshwaran N. Functional finishing in cotton fabrics using zinc oxide nanoparticles. Bulletin of Materials Science, 2006; 29 (6): 641-645.

Yamamoto K. Crease-resistance treatments of cotton fabrics with non-formaldehyde crosslinking agents. Textile Research Journal, 1982; 52 (6): 357-362.

Yi S-H, Choi S-K, Jang J-M, Kim J-A,Jung W-G. Lowtemperature growth of $\mathrm{ZnO}$ nanorods by chemical bath deposition. Journal of colloid and interface science, 2007; 313 (2): 705-710.

\section{How to cite this article:}

Mohamed FA, Ibrahim HM, El-Kharadly EA, El-Alfy EA Improving Dye ability and antimicrobial properties of Cotton Fabric. J App Pharm Sci, 2016; 6 (02): 119-123. 